\title{
What Happened to the Soviet Superpower's Nuclear Arsenal? Clues for the Nuclear Security Summit
}

\section{Citation}

Allison, Graham. 2012. What Happened to the Soviet Superpower's Nuclear Arsenal? Clues for the Nuclear Security Summit. HKS Faculty Research Working Paper Series RWP12-038, John F. Kennedy School of Government, Harvard University.

\section{Published Version}

http://web.hks.harvard.edu/publications/workingpapers/citation.aspx?Publd=8514

\section{Permanent link}

http://nrs.harvard.edu/urn-3:HUL.InstRepos:9403176

\section{Terms of Use}

This article was downloaded from Harvard University's DASH repository, and is made available under the terms and conditions applicable to Other Posted Material, as set forth at http:// nrs.harvard.edu/urn-3:HUL.InstRepos:dash.current.terms-of-use\#LAA

\section{Share Your Story}

The Harvard community has made this article openly available.

Please share how this access benefits you. Submit a story.

\section{Accessibility}




\section{What Happened to the Soviet Superpower's Nuclear Arsenal? Clues for the Nuclear Security Summit Faculty Research Working Paper Series}

\section{Graham Allison}

Harvard Kennedy School

\section{August 2012 RWP12-038}

Visit the HKS Faculty Research Working Paper series at:

http://web.hks. harvard.edu/publications

The views expressed in the HKS Faculty Research Working Paper Series are those of the author(s) and do not necessarily reflect those of the John F. Kennedy School of Government or of Harvard University. Faculty Research Working Papers have not undergone formal review and approval. Such papers are included in this series to elicit feedback and to encourage debate on important public policy challenges. Copyright belongs to the author(s). Papers may be downloaded for personal use only. 


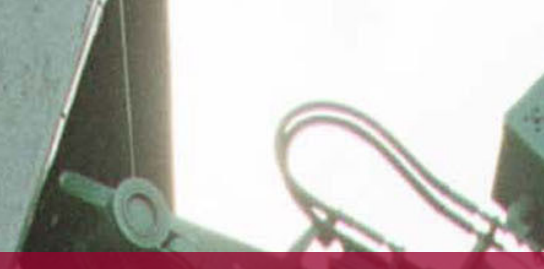

\section{WHAT HAPPENED TO THE SOVIET SUPERPOWER'S NUCLEAR ARSENAL? CLUES FOR THE NUCLEAR SECURITY SUMMIT}

GRAHAM ALLISON
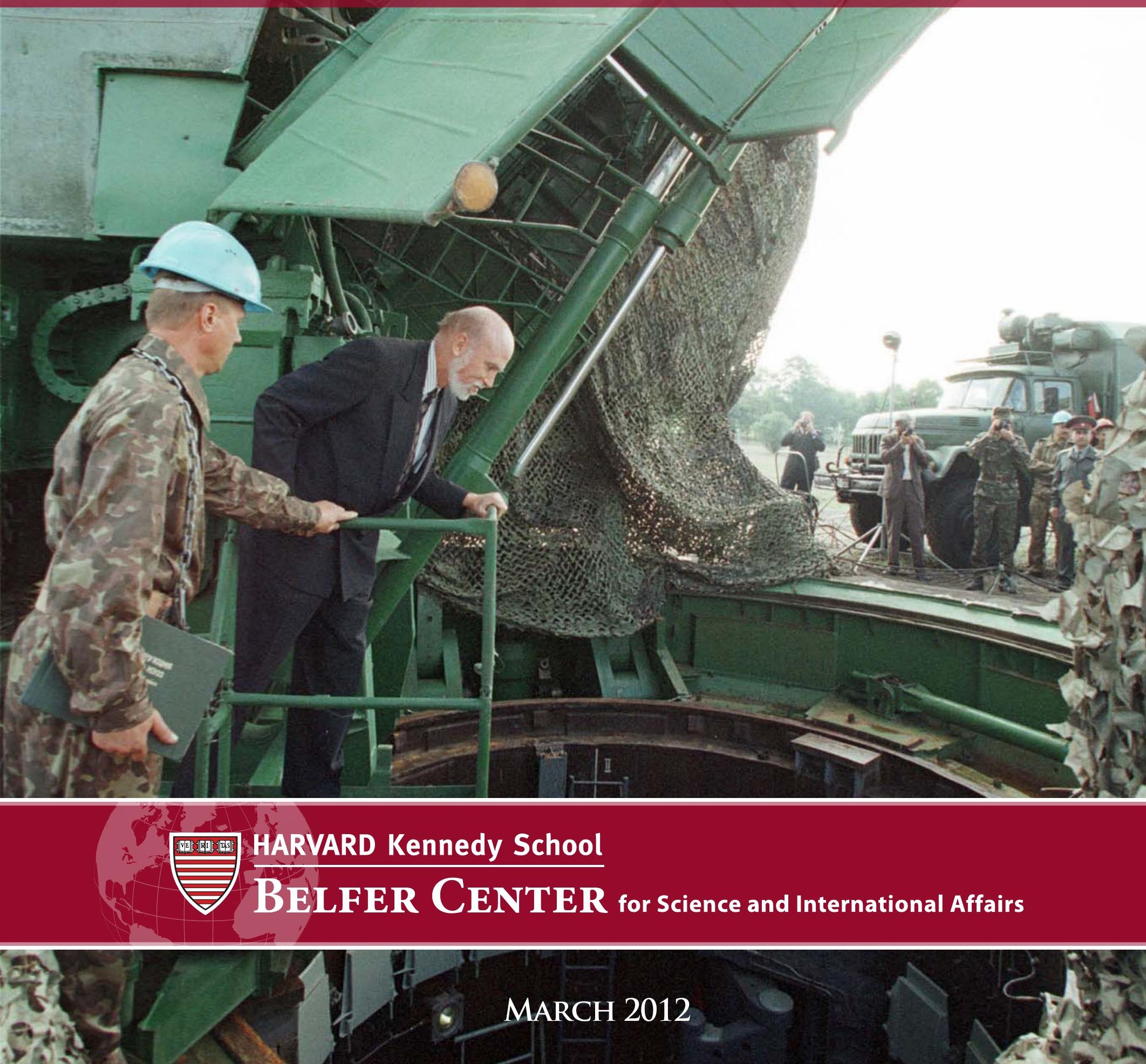


\title{
Discussion Paper \#2012 - 04
}

\author{
Belfer Center for Science and International Affairs \\ John F. Kennedy School of Government \\ Harvard University \\ 79 JFK Street \\ Cambridge, MA 02138 \\ Fax: (617) 495-8963 \\ Email: bcsia_ksg@harvard.edu \\ Website: http://belfercenter.org
}

Copyright 2012 President and Fellows of Harvard College

The author of this report invites use of this information for educational purposes, requiring only that the reproduced material clearly cite the full source: Allison, Graham. "What Happened to the Soviet Superpower's Nuclear Arsenal? Clues for the Nuclear Security Summit." Discussion Paper 2012-04, Belfer Center for Science and International Affairs, Harvard Kennedy School, March 2012.

Statements and views expressed in this discussion paper are solely those of the author and do not imply endorsement by Harvard University, the Harvard Kennedy School, or the Belfer Center for Science and International Affairs.

Cover Image: In this 1998 photo taken in Pervomaisk, Ukraine, a senior U.S. defense official, second left, looks into a Soviet SS-24 ballistic missile silo which was to be eliminated in accordance with the Treaty on the Reduction and Limitation of Strategic Offensive Arms. Photo by Associated Press.

Layout by Courtney Anderson 


\section{Acknowledgements}

The author would like to thank Simon Saradzhyan, Research Fellow at the Belfer Center for Science and International Affairs; Melanie Getreuer, former Research Assistant at the Belfer Center for Science and International Affairs; and Ben Rhode, Research Associate at the Belfer Center for Science and International Affairs for their help in preparing this paper. 


\section{TABLE OF CONTENTS}

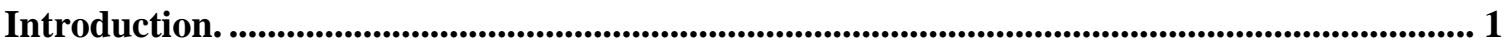

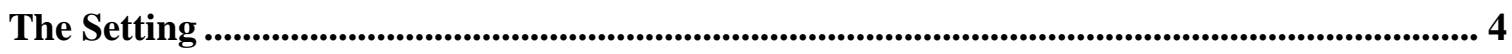

Step-By-Step: What Happened To Soviet Nukes?............................................................................... 6

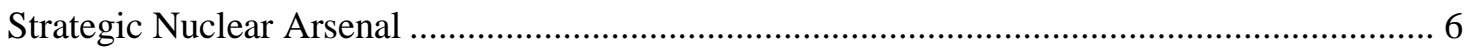

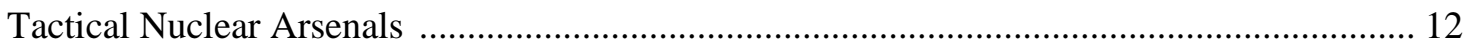

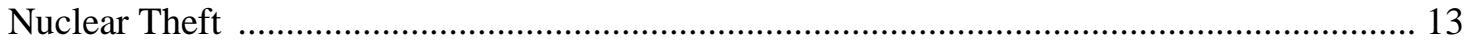

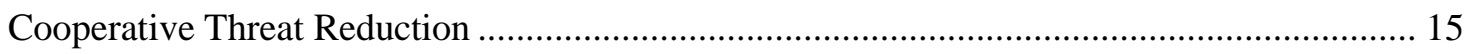

Lessons Learned …............................................................................................................................ 20

Next Step: Global Alliance Against Nuclear Terrorism .................................................................. 23

Appendix: Graham Allison's Memo to Colin Powell. .................................................................. 28 


\section{INTRODUCTION}

"If the Soviets do an excellent job at retaining control over

their stockpile of nuclear weapons - let's assume they've

got 25,000 - and they are 99 percent successful, that would

mean you could still have as many as 250 that they were

not able to control."

Dick Cheney, "Meet the Press," December 1991

When leaders from 53 countries convene at the second Nuclear Security Summit in Seoul this March, they will review the substantial progress that has been made in securing nuclear weapons and materials worldwide since the inaugural summit in Washington two years ago, as well as what still remains to be done.

On the one hand, there can be no question that by focusing like a laser beam on the issue of securing nuclear weapons and materials beyond the reach of thieves and terrorists, persuading participants in the 2010 Summit to pledge that by 2014 all such materials will be either secured or eliminated, and working with states case-by-case to consolidate, secure, and indeed eliminate weapons-usable material, this effort has made the world a safer place. On the other, despite many notable advances and a laudable boost in general awareness of the problem, too many weapons and too much material remain at risk. The pace of preventative actions taken does not yet match the threat. Securing all weapons and materials is an immense political and logistical challenge. But the consequences of failing to do so could be truly catastrophic. The Seoul summit will play an indispensable role in moving governments to address this challenge with the vigor it demands.

The international community has faced similar challenges before, perhaps ones even more daunting. To stretch our imagination about what can conceivably be done, and provide some historical perspective on the task remaining before us, it may be instructive 
to review what actually happened when a nuclear power became a failed state in December 1991.

Twenty years ago Russia and fourteen other newly-independent states emerged from the ruins of the Soviet empire, many as nations for the first time in history. As is typical in the aftermath of the collapse of an empire, this was followed by a period of chaos, confusion, and corruption. As the saying went at the time, "everything is for sale." At that same moment, as the Soviet state imploded, 35,000 nuclear weapons remained at thousands of sites across a vast Eurasian landmass that stretched across eleven time zones.

Today, fourteen of the fifteen successor states to the Soviet Union are nuclear weaponsfree. When the U.S.S.R. disappeared, 3,200 strategic nuclear warheads remained in Ukraine, Kazakhstan, and Belarus, most of them atop intercontinental ballistic missiles (ICBMs) that stood on alert, ready to be fired at targets in the U.S. Today, every one of the nuclear weapons in Ukraine, Kazakhstan, and Belarus has been deactivated and returned to Russia, where they were dismantled and the nuclear material in the warheads blended down to produce fuel for civilian reactors.

Strategic nuclear weapons are nuclear warheads aimed at an adversary's nuclear weapons, cities and military infrastructure. Typically, they are large in yield and heavy. Of greater interest to terrorists, however, were the former U.S.S.R's 22,000 tactical nuclear weapons with smaller yields and shorter ranges. These were designed primarily for battlefield use, with some small enough to fit into a duffel bag. Today, all of these have also been returned to Russia, leaving zero nuclear weapons in any other state of the former Soviet Union.

Former Czech president Vaclav Havel observed about the rush of events in the 1990s: "things have changed so fast we have not yet taken time to be astonished." Perhaps the most astonishing fact about the past twenty years is something that did not happen. Despite the risk realistically estimated by former Secretary of Defense Dick Cheney in 
December 1991, two decades have passed without the discovery of a single nuclear weapon outside Russia.

This paper will address the question: how did this happen? Looking ahead, it will consider what clues we can extract from the success in denuclearizing fourteen postSoviet states that can inform our non-proliferation and nuclear security efforts in the future. These clues may inform leaders of the U.S., Russia, and other responsible nations attending the Seoul Nuclear Security Summit on March 26-27, 2012. The paper will conclude with specific recommendations, some exceedingly ambitious that world leaders could follow to build on the Seoul summit's achievements against nuclear terrorism in the period before the next summit in 2014. One of these would be to establish a Global Alliance Against Nuclear Terrorism. 


\section{THE SETTING}

As fate would have it, I was in Moscow in August 1991 when a group of conservatives in the Soviet security establishment attempted to overthrow President Mikhail Gorbachev. Tanks commanded by the plotters ringed the Kremlin; Gorbachev, then on vacation in the southern part of the country, was placed under house arrest. With a longtime Russian friend, Andrei Kokoshin, later the national security advisor to Russian President Boris Yeltsin, I inspected the tank battalion and other military units surrounding the Kremlin and elsewhere in Moscow. As we walked and talked, it became clear to both of us that the coup would fail and that the Soviet superpower was soon to be no more.

On the plane back to the U.S., I wrote a private memorandum to the Chairman of the Joint Chiefs of Staff at that time, Colin Powell, with whom I had worked in the Reagan administration. Entitled "Sounding the Alarm," that memo stated: "Soviet disunion could create additional nuclear states, provoke struggles for control of Soviet nuclear weapons, and lead to a loss of control of strategic or non-strategic nuclear weapons." Since these events are now history, and the memo was private but not classified, it is attached here as appendix.

Could the newly-independent former Soviet states, having been dominated by Russia for centuries, be persuaded to give up the nuclear weapons within their borders? To many of them, a nuclear deterrent appeared to be the best guarantor of independent survival and security. Fatalists dismissed the proposal to eliminate these arsenals as a fool's errand. Nonetheless, as a result of a bold strategy that defined a bright red line of zero nuclear weapons in these states, established deep U.S.-Russian cooperation, and carefully employed the full array of carrots and sticks, Ukraine, Kazakhstan, and Belarus each agreed in 1994 to eliminate all nuclear weapons on their soil. By the end of 1996, every one of the 3,200 strategic nuclear warheads in these states had been deactivated and returned to Russia. In addition, 14,000 Soviet tactical nuclear warheads that had been deployed outside Russia were returned, and many of them dismantled. 
In what was not only a strategic, but also a logistical triumph, Russian military and security services managed to maintain control of tactical warheads, to load them onto trucks, trains, and aircraft, and to return them to secure storage sites in Russia. As a former DHL executive observed, this would have been an extremely demanding assignment even for the "world's leading package delivery service," let alone for a state apparatus beset by organizational crises. 


\section{STEP-BY-STEP: WHAT HAPPENED TO SOVIET NUKES?}

The collapse of the former Soviet Union presented policy-makers with three unique nuclear challenges. The first was to address the fact that Soviet strategic nuclear weapons — principally its nuclear-armed ICBMs - were located in four of the Soviet successor states, raising the prospect that the demise of the Soviet Union would result in the emergence of several states with intercontinental nuclear arsenals. The second was to secure and consolidate the Soviet Union's far-flung arsenal of tactical nuclear weapons, the type that would be most transportable to a terrorist group or rogue state in search of an instant nuclear capability. The third was to prevent the theft of nuclear weapons or weapons-usable material from Russia, or elsewhere in the former Soviet Union.

\section{Strategic Nuclear Arsenal}

Competition for ownership and control of the Soviet Union's strategic nuclear forces posed the most urgent challenge. When the U.S.S.R. collapsed, the former Soviet strategic arsenal was left in Ukraine, Kazakhstan, and Belarus, as well as in Russia. President George H.W. Bush had no problem identifying the best feasible outcome for the U.S.: a single nuclear successor state, Russia. Russia's national security establishment strongly agreed.

Numerous obstacles lay between American and Russian preferences and their realization, particularly in the case of Ukraine. Belarus was a much less serious concern because of its subservience to Moscow. Kazakhstan wavered only briefly before the pragmatic policies of President Nursultan Nazarbayev set his republic firmly on a course toward total denuclearization, a status it achieved when the last nuclear warhead was removed from Kazakh territory in April 1995. 
Ukraine, however, had a simple and intuitively compelling reason for wanting to retain a minimal nuclear deterrent: to assure its independence from Russia. As Ukraine's thenDefense Minister Konstantin Morozov, a key player in the negotiations that ended in the elimination of nuclear weapons in Ukraine, put it plainly: "Ukraine would have posed no threat to anyone if, hypothetically speaking, it had possessed tactical nuclear weapons. Such weapons could have deterred Russia in its unfriendly political and economic lunges at Ukraine."

Moreover, thoughtful American voices counseled Ukrainians that the best possible guarantor of that independence lay in an independent nuclear deterrent. According to Zbigniew Brzezinski (President Carter's national security advisor), the Clinton administration's focus on Ukraine's nuclear status was misplaced. ${ }^{2}$ In reality, Brzezinski argued, the continued strength of Russia's age-old "imperial impulse" necessitated that the U.S. recognize "the fact that Ukraine's independent existence is a matter of far greater long-range significance than whether Kiev does or does not promptly dismantle its postSoviet nuclear arsenal."”3 American political scientist John Mearsheimer concurred with Brzezinski's assessment: "Ukrainian nuclear weapons are the only reliable deterrent to Russian aggression."

Had Ukraine retained the strategic nuclear weapons it inherited from the former Soviet Union, it would instantly have become the third largest nuclear weapons power in the world. The implications of this fact for U.S. national security can hardly be exaggerated. Some 1,250 nuclear warheads on ICBMs targeting American cities would have come under the command of a new and unstable government in Kiev.

In one of its first and most consequential national security initiatives, the Clinton administration moved in 1993 to engage Ukraine in a multi-dimensional relationship aimed at ensuring prompt and complete denuclearization. As Assistant Secretary of

\footnotetext{
${ }^{1}$ Konstantin Morozov's communication with author, April 14, 2011.

${ }^{2}$ Zbigniew Brzezinski, "The Premature Partnership," Foreign Affairs, Vol. 73, Issue 2 (March/April 1994).

${ }^{3}$ Ibid.

2 John J. Mearsheimer, "The Case for a Ukrainian Nuclear Deterrent," Foreign Affairs, Vol. 72, No. 3 (Summer 1993).
} 
Defense with lead responsibility for the former Soviet Union, I participated in the new administration's development of a strategy for achieving this ambitious objective. That strategy had five major strands.

First, the U.S. sought to persuade Ukraine's new leaders that nuclear weapons were not the solution to their security problem, but rather a target that could provoke a Russian attack. Initially, the military chain of command of strategic nuclear forces in Ukraine ran from Moscow to Strategic Missile Forces officers in Ukraine. After Ukrainian president Leonid Kravchuk forced military officers serving in Ukraine to swear sole allegiance to the new Ukrainian state, questions of command and control of weapons became more ambiguous. On the one hand, Moscow continued to control the codes required to unlock and launch nuclear-tipped missiles. On the other, many of these technical systems had been developed by scientists and engineers in Ukraine - who were now coming to think of themselves as Ukrainians.

Those of us at the Defense Department were acutely aware of the possibility that a contest for control of nuclear weapons in Ukraine, or an attack upon them, could trigger an accidental launch of warheads that would destroy American cities. The vaunted SS$24 \mathrm{~s}$ carried ten independently targeted warheads with a yield of 550 kilotons each, all aimed at American targets.

Thus, the message from the U.S. Department of Defense to Ukrainian Minister of Defense Morozov, the Ukrainian national security advisor, and Ukraine's president was that the nuclear arsenal in Ukraine threatened American national security. On repeated occasions, as Assistant Secretary, I told Ukrainian counterparts that if I were an advisor to the Russian General Staff and concluded that Ukraine was about to take operational control of nuclear-armed ICBMs, I would advise attacking the weapons and facilities to prevent that outcome.

Second, U.S. strategy sought to persuade Ukraine's leaders that its best hope for survival in a dangerous world, especially since it shared a long, yet undetermined border with a 
wounded bear that had for the previous millennium dominated Kiev, lay in establishing a real relationship with the U.S.. As the sole remaining superpower, the U.S. was unambiguously number one. Washington was, we told the new leaders of Ukraine, prepared to enhance military-to-military relations with a non-nuclear Ukraine. As the world's economic superpower, the U.S. was also the gatekeeper to the economic and technical assistance Ukraine sorely needed from the World Bank and the IMF. U.S. assistance to Ukraine would be conditioned on their elimination of nuclear weapons.

Third, U.S. strategy underscored for Ukrainians the real dangers posed by nuclear weapons. Just seven years earlier, Ukraine had experienced the nightmare of Chernobyl. A civilian nuclear power plant had melted down, releasing highly radioactive material across a large swathe of Ukraine and Belarus. Every new member of the Ukrainian government and military had a personal story about the devastating consequences of that tragedy. Earlier, as a member in a Harvard project that provided economic and political advice to the emerging government in Kiev, I had created the first bumper sticker for the newly independent Ukraine. It warned in both Russian and Ukrainian: "Every nuclear weapon is a Chernobyl just about to happen.”

As negotiations over the nuclear weapons dragged on, and evidence of Ukraine's seriousness about taking operational control of nuclear weapons mounted, Russian negotiators struck a responsive chord by arguing that the weapons in Ukraine had passed their "service warranty" and were at risk of leaking radiation or even exploding. The U.S. did nothing to deflate such exaggeration. Morozov, Ukraine's then-Defense Minister, believes to this day that Ukraine could not have ensured the safe operation of nuclear weapons on its territory. According to Morozov, Ukraine had "no technological capacity for ensuring safe operation of nuclear weapons." In fact, when asked to name the top three reasons why Ukraine gave up nuclear weapons, Morozov cited (1) the unpredictable consequences that the Ukrainian government would have had to face if it had decided to claim command and control of the nuclear weapons deployed in Ukraine; (2) the lack of technical preparations that would have been needed to take over their maintenance and 
operation quickly; and (3) the need for Ukraine to comply with the Nuclear NonProliferation Treaty (NPT). ${ }^{3}$

Fourth, the U.S. strategy for denuclearizing Ukraine also engaged Russia. Here, the U.S. and Russia shared a vital national interest. Even though Ukraine had joined the Commonwealth of Independent States, Russia felt threatened by Ukraine's potential nuclear-armed status. As Russia’s Defense Minister at that time, Pavel Grachev noted: "Russia could not allow the emergence of a new nuclear neighbor, even if that neighbor were a friendly state."4 A senior Russian diplomat involved in the negotiations on denuclearization put it more delicately, observing that Russia had "no need for any new nuclear states, friendly or not."5

Of course, Russia had many other outstanding issues with Ukraine including clarification of the status of Crimea, ownership of the Black Sea Fleet, and indeed, for most of the Russian national security establishment, even allowing Ukraine to become an independent state. Nonetheless, toward the common goal of denuclearizing Ukraine, the U.S. and Russia developed a well-coordinated, often good cop-bad cop approach. On occasion, Russians objected that the U.S. was being deceived or even seduced by Ukraine. Russian Defense Minister Grachev, in particular, complained to me about Secretary of Defense Les Aspin playing "huggy huggy" with his Ukrainian counterpart. I responded that, in the U.S., we have a saying that it is sometimes useful to hug someone — in order to be able to squeeze him.

Finally, the U.S. strategy included allocating a substantial part of the Nunn-Lugar Cooperative Threat Reduction program in the former Soviet Union to Ukraine (and Russia) to incentivize desired behavior. Initially funded at $\$ 400$ million per year, the Nunn-Lugar program grew to a $\$ 1$ billion per year program managed principally by the Department of Defense. At a time when Ukraine's new military establishment was

\footnotetext{
${ }^{3}$ Morozov's communication with author.

${ }^{4}$ Pavel Grachev's communication with author, February 7, 2011.

${ }^{5}$ Remarks made by a senior Russian diplomat to the author on October 25, 2010 in Cambridge, MA. The diplomat — who is intimately familiar with the negotiations on denuclearization of Ukraine — asked not to be named.
} 
struggling for resources, U.S. financial assistance was the Ukrainian government's best source of scarce dollars. ${ }^{6}$

Much of the U.S.-Russian diplomacy was carried out in the context of the GoreChernomyrdin Commission, a biannual forum convened by Russian Prime Minister Victor Chernomyrdin and U.S. Vice President Al Gore that brought together senior Russian and American officials for high-profile, and often highly technical, negotiations. Vice President Gore brokered the deal that gave new impetus the denuclearization of Ukraine at the end of 1993, an arrangement that was set forth in the "Trilateral Agreement" signed by U.S. President Bill Clinton, Russian President Boris Yeltsin, and Ukrainian President Leonid Kravchuk at a summit in January 1994 in Moscow.

The Trilateral Agreement formalized one of the Clinton administration's most significant achievements: it established the framework for Ukraine to transfer all strategic nuclear warheads on its soil to Russia for dismantlement; to accede to NPT as a non-nuclear weapons state; and, thus, to allow the START I Treaty to enter into force. In return, Russia agreed to ship nuclear fuel rods to Ukraine for use in civilian power reactors, and Russia and the U.S. together provided formal assurances of Ukraine's independence and territorial integrity.

After the fact, it is difficult to imagine what might have been. What if Ukraine had attempted to seize operational control of ICBMs with strategic nuclear warheads? What if during such an effort, Russia had attacked the missile silos? What if, in that chaos, an accident had triggered the launch of one missile with ten nuclear warheads against American cities? At the time, these were all considered serious and credible threats.

\footnotetext{
${ }^{6}$ U.S. assistance to Ukraine totalled \$4 billion between 1991 and 2011. "Background Note: Ukraine," Bureau of European and Eurasian Affairs, U.S. Department of State, January 4, 2012. 


\section{Tactical Nuclear Arsenals}

The total size of the Soviet tactical nuclear weapons arsenal remains unknown.

According to best estimates, however, at least 22,000 tactical nuclear weapons were stationed across the Soviet Union's fifteen constituent republics in 1991. In the context of increasing turmoil within the ranks of the Soviet military and rising instability along the Soviet periphery, especially in the conflict-ridden republics such as Armenia, Azerbaijan, Georgia, and Tajikistan, the Soviet Union's tactical nuclear weapons arsenal presented an acute risk. If stolen and offered for sale in international arms bazaars, there would have been many eager buyers, including not only rogue states but also terrorist groups. We sometimes referred to these hypothetical "loose nukes" as "Cheney's 250."

Recognizing this risk, the U.S. and Russian governments undertook a series of initiatives in the early 1990s to reduce their arsenals of tactical nuclear weapons. Later dubbed "Presidential Nuclear Initiatives" (PNIs), these were "reciprocal unilateral commitments," which meant that they were unilateral, not legally binding and reversible, calling for an appropriate but voluntary response. ${ }^{4}$

The first of these unprecedented initiatives occurred in September 1991 — just one month after the failed coup in Moscow. President George H.W. Bush announced the unilateral withdrawal of tactical nuclear weapons from U.S. forces around the world, a sweeping initiative that reversed in a single stroke decades of U.S. military planning. In announcing these actions, President Bush challenged his Soviet counterpart, Mikhail Gorbachev, to undertake a reciprocal withdrawal of tactical nuclear weapons from his military forces abroad, a process that, in fact, Moscow had already begun, albeit on a modest scale.

\footnotetext{
${ }^{4}$ Eli Corin, "Presidential Nuclear Initiatives: An Alternative Paradigm for Arms Control," Center for Nonproliferation Studies, Monterey Institute of International Studies and The Nuclear Threat Initiative, March 2004.
} 
A week after President Bush's initiative, Gorbachev responded positively in his own public address, outlining a reciprocal plan for withdrawing all tactical nuclear weapons from the outer reaches of the Soviet empire.

Less than a month after moving into the Kremlin in December 1991 Boris Yeltsin reiterated and even expanded Gorbachev's commitment to these efforts. In his January 1992 statement the Russian president said that the new Russia would continue to adhere to all bilateral and multilateral agreements related to nuclear weapons control and that his country would continue to work towards global nuclear disarmament "gradually on a parity basis." 5

Yeltsin's continued commitment to this process led over the next twelve months to the removal of tactical nuclear weapons from newly independent states that were formerly part of the Soviet Union and their consolidation at central storage facilities in Russia. A total of 14,000 warheads were moved from non-Russian states, most of them subsequently dismantled, and their nuclear cores downblended into fuel.

\section{Nuclear Theft}

The third nuclear challenge of the post-Soviet era was qualitatively different and orders of magnitude more difficult than the first two. Solutions to the first two problems succeeded in concentrating the former Soviet nuclear arsenal within Russia.

The good news: all nuclear weapons had been retrieved from the fragile former Soviet states. The bad news: the weapons were returned to Russia during a period of considerable chaos. Thousands of nuclear weapons and hundreds of thousands of pounds of weapons-usable fissile material were being held at scores of sites scattered across a disoriented, discombobulated Russian Federation. Security was so insufficient at some of Russia's nuclear facilities at that time that stealing highly enriched uranium (HEU) was

\footnotetext{
${ }^{5}$ Ibid.
} 
easier than taking potatoes, according to a Russian military investigator who probed the theft of four kilograms of HEU by a Navy officer in $1993 .^{7}$

The U.S.S.R. had relied on the strong hand of the state and absolute control over society to deter theft of its nuclear arsenal. The Soviet Union's dissolution thus created an international security problem without precedent: nuclear weapons and materials were being stored in installations that lacked adequate security, often located in highly unstable areas. The risk that insiders, or a combination of insiders and intruders, would steal former Soviet nuclear weapons and materials loomed large.

In these early days of the Soviet collapse, American and Soviet policy had not yet begun to address this problem in a manner that was commensurate with their countries' stakes in the issue. Between 1992 and 1994, U.S. initiatives designed to combat the threat of nuclear theft were carried out in the context of the Nunn-Lugar program within the Department of Defense. The effectiveness of this early effort suffered from an array of legal restrictions and bureaucratic obstacles, handicapping the program's efforts to improve the security of Russian fissile material quickly and comprehensively. Responsibility for implementing the various U.S. anti-theft programs was broadened in 1994-95. Although this bureaucratic adaptation began to show a few promising results in 1995, the overall U.S. government effort still moved too slowly.

And yet, the bottom line is clear: not a single former Soviet nuclear weapon has been found in another country or in an international arms bazaar. Were it not for the intense professionalism, patriotism, and devotion to duty of the vast majority of the nuclear scientists and workers in the former Soviet states, a genuine nuclear proliferation catastrophe would surely have occurred. This incredible result is testimony to the determined efforts of the Russian government, including, in particular, the "nuclear guardians" in its Ministry of Defense and Ministry of Atomic Energy, supported by U.S.

\footnotetext{
${ }^{7}$ Oleg Bukharin and William Potter, "Potatoes Were Guarded Better," Bulletin of the Atomic Scientists, (May 1995- June 1995.)
} 
technical and economic assistance stemming from the Nunn-Lugar legislation and subsequent acts of Congress.

\section{Cooperative Threat Reduction}

In December 1991, as the Soviet Union - the "Evil Empire," as Ronald Reagan rightly named it - wobbled on the brink of collapse, U.S. Secretary of Defense Dick Cheney appeared on "Meet the Press." The moderator asked what would happen to its nuclear weapons if the Soviet Union broke up.

As quoted at the outset, he answered: "If the Soviets do an excellent job at retaining control over their stockpile of nuclear weapons - let's assume they've got 25,000 — and they are 99 percent successful, that would mean you could still have as many as 250 that they were not able to control."

Asked a follow-up question about what the U.S. could do to address this threat, Cheney was unable to think of anything other than to be prepared for the worse. As he said: "Given the disintegration of their society, given the sad state of their economy, the only realistic thing for me to do as Secretary of Defense is to anticipate that one of the byproducts of the breakup of the Soviet Union will be the proliferation of nuclear weapons." $" 8$

Fortunately, others in Washington would answer the question about what the U.S. would do. A leading Democratic Senator from Georgia, Sam Nunn, and a Republican Senator from Indiana, Dick Lugar, not only recognized the challenge but also created a breathtaking response. Too late in the Congressional calendar to hold hearings on the issue, they designed an imaginative and unprecedented legislative maneuver by which they attached an amendment to the Defense Appropriations Bill. It took money

\footnotetext{
${ }^{8}$ Cited in Graham Allison. "Washington Can Work: Celebrating Twenty Years With Zero Nuclear Terrorism." The Huffington Post, December 29, 2011.
} 
appropriated for the U.S. defense budget and allowed the Secretary of Defense to spend \$400 million, helping Russia to secure and eliminate former Soviet nuclear weapons. In what has been the most significant U.S. policy initiative towards Russia in the post-Cold War period to date, it was not the chief executive, but rather, leaders in the Congress, who both put the problem on the agenda and legislated the program of action to address it.

However, after an initial burst of imagination and energy, the Cooperative Threat Reduction Program — that Lugar and Nunn legislated - soon became enmeshed in bureaucratic "business as usual." Cold War habits of thought began to re-emerge. Russian suspicions about espionage by the U.S. government, American complaints of diversion of funds by the Russians, resistance to anything "not invented here," and deeply ingrained attitudes and practices created obstacles that could be overcome only by high-level interventions.

Thus, at the end of the Clinton administration, in a notable "Report Card" on U.S. nonproliferation programs with Russia, an official task force chaired by Howard Baker and Lloyd Cutler concluded that the "existing scope, pace, and operation of the programs leave an unacceptable risk of failure and the potential for catastrophic consequences." The Baker-Cutler Report Card called for a reinvention of this enterprise to "finish the job" of securing all weapons and material on a fast track with full funding, which they estimated would cost $\$ 30$ billion.

The administration of George W. Bush entered office in 2001 skeptical of the NunnLugar program. It was only after months of delay and initial cuts to the program's budget that the administration responded to sharp criticism from Republican Senator Lugar and others, restoring the funding to the levels during the Clinton administration.

One major contribution to the strengthening of nuclear security in the former Soviet Union that President Bush did make early in his first term was the lead role he played in the establishment of the Global Partnership Against the Spread of Weapons and Materials 
of Mass Destruction at the G-8 Kananaskis Summit in June 2002. G-8 leaders pledged to spend $\$ 20$ billion over the following decade to assist Russia and the other former Soviet states in securing or eliminating chemical, biological, and nuclear weapons.

Management of the Nunn-Lugar program, however, was left to new officials with little enthusiasm for the task. Episodic initiatives, heroic efforts by isolated individuals, and occasional presidential declarations aside, the program sank deeper into the bureaucracies on both sides. At the end of the Bush administration's first term, after thirteen years of effort since the fall of the Soviet Union, the nuclear security balance sheet showed that the job of securing Russia's nuclear weapons and material remained only half done, leaving 44,000 potential nuclear weapons' worth of HEU and plutonium vulnerable to theft. To be sure, the job was physically and politically ambitious in the extreme. But keeping at that pace, at that time terrorists would have had 13 more years to try their luck.

In February 2005 a U.S.-Russian summit in Bratislava, Slovakia provided a new opportunity to boost cooperation in reducing nuclear threats. For the first time, President Bush and his Russian counterpart Vladimir Putin accepted personal responsibility for addressing the nuclear threat and for ensuring that their governments secured all potentially loose nuclear material in their countries by the end of 2008. They pledged that all U.S. and Russian research reactors provided to developing and transitional countries would be converted from HEU to low-enriched uranium fuel, from which nuclear weapons cannot be made. They also created a "Senior Interagency Group," chaired by Energy Secretary Samuel W. Bodman and Russian Federal Atomic Energy Agency Chief Alexander Rumyantsev, to oversee implementation of these efforts and brief them regularly.

Also in 2005, the United Nations General Assembly adopted the International Convention for the Suppression of Acts of Nuclear Terrorism. Proposed by Russia to strengthen the international law to counter terrorist threats, the April 2005 pact became the first UN convention aimed at preventing WMD terrorist attacks. The following year, Bush and Putin launched the Global Initiative to Combat Nuclear Terrorism, which helps 
nations improve their capacity for prevention, detection, and response to a nuclearterrorist event. Since July 2006, 80 nations have joined the U.S. and Russia as members of this initiative. The depth of convergence of U.S. and Russian vital national interests on the issue of nuclear security is best illustrated by the fact that bilateral cooperation on this issue continued even as relations between the two countries became frosty in the aftermath of the August 2008 war in which Russia sided with Georgia's separatist provinces of South Ossetia and Abkhazia.

One of President Obama's highest foreign policy priorities after he took the oath of office in January 2009 was to "reset" relations with Russia as a pillar in his strategy to combat nuclear terrorism, which he called "the single largest threat to American national security.” In July 2009, Obama and Russian President Dmitry Medvedev established a framework for sustainable cooperation between their governments, launching a bilateral presidential commission that included working groups on nuclear security, arms control and counter-terrorism.

In April 2010, Obama and Medvedev signed the New START treaty to reduce the number of strategic nuclear weapons and decrease the probability that such weapons or their constituent materials could be acquired by terrorists. The same month saw the Russian president participate enthusiastically in the Nuclear Security Summit organized by Obama in Washington, making specific national nuclear security commitments. Medvedev and 45 other heads of state and government joined President Obama in supporting his plan to secure all vulnerable nuclear material worldwide within four years, and called for specific standards for securing HEU and plutonium. All the participating leaders approved a detailed work plan that provides for compliance with past United Nations Security Council resolutions on nuclear security. Also, 29 countries made specific commitments at the summit to secure or eliminate nuclear materials, although most of these commitments either restated earlier promises or confirmed what these states had planned to do regardless. As part of these commitments, Russia signed a protocol with the U.S. to amend one of the cornerstones of the Nunn-Lugar programs in Russia the 2000 Plutonium Management and Disposition Agreement. Under the amended 
agreement, both countries will dispose of approximately 17,000 nuclear weapons' worth of excess weapon-grade plutonium.

In June 2010, Obama and Medvedev joined other G-8 leaders in extending the group's Global Partnership Against WMD for another ten years, with the U.S. pledging an additional $\$ 10$ billion for the program. Also as part of the reset, the U.S.-Russian 123 agreement on civilian nuclear cooperation came into force in January 2011. The two countries are currently negotiating extension of the umbrella agreement for the Cooperative Threat Reduction (CTR) Programs, which expires in 2013.

These programs, into which 20 billion American taxpayers' dollars have been invested over the past twenty years, remain the most cost-effective expenditure in the U.S. defense budget. CTR has financed the aforementioned withdrawal of 3,200 strategic nuclear warheads from Ukraine, Kazakhstan, and Belarus. 14,000 tactical nuclear weapons have been withdrawn to Russia. More than 2,370 strategic missiles, 155 strategic bombers, and 33 ballistic-missile submarines have been destroyed as part of the ongoing CTR programs. Yet how many Americans know that half of all the electricity produced by nuclear power plants in the U.S. is powered by fuel that had previously been in Russian warheads, but was purchased in one of the CTR programs? When this purchase program, known as Megatons to Megawatts, is completed in 2013, the equivalent of 20,000 warheads will have been reprocessed into fuel - enough to power all of the nuclear reactors in the entire U.S. for two years. ${ }^{9}$

\footnotetext{
9 "Megatons to Megawatts," official web site of the United States Enrichment Corporation, http://www.usec.com/russian-contracts/megatons-megawatts.
} 


\section{LESSONS LEARNED}

At the end of this March, President Obama will go to Seoul to join Lee Myung-bak and 52 other heads of state for the second Nuclear Security Summit. That event offers an appropriate occasion for looking back on the remarkable accomplishments of the past two decades for lessons for the future. Lessons about assistance in denuclearization, about the unilateral elimination of nuclear weapons, and about bilateral and multilateral cooperation in securing nuclear weapons and materials can be applauded and adapted to assure that the record of zero nuclear explosions in cities over the past two decades is maintained for the decade ahead, and beyond.

Of these lessons, it is the denuclearization of fourteen former Soviet states that demonstrates most vividly how effective, ambitious nuclear diplomacy can and should be at a time when the international community struggles to prevent a meltdown of the global nuclear order undermined by the nuclear programs of North Korea and Iran.

First, and most obviously, denuclearization of Ukraine demonstrates that persuading states to surrender their nuclear arsenals is very difficult, but not impossible. Nuclear weapons tend to be viewed as a state's surest security blanket. Thus, when Ukraine felt increasingly vulnerable to Russian revanchism and estranged from the U.S., this military asset was increasingly attractive. The challenge for Washington and Moscow was to convince Ukraine that surrendering its nuclear arsenal would be better for its security than the alternative.

In the case of Kiev, Washington's and Moscow's appeal was two-pronged. First, they declared that Ukraine's retention of its strategic arsenal was unacceptable, and they unwaveringly committed themselves to the arsenal's removal. ${ }^{10}$ Second, they combined this commitment to denuclearization with economic, diplomatic, and security guarantees. Ukraine had to make a decision: to relinquish its strategic arsenal, giving up a potential

\footnotetext{
${ }^{10}$ Ashton Carter and William J. Perry, Preventive Defense: A New Security Strategy for America (Washington, DC: Brookings Institution Press, 1999).
} 
nuclear deterrent but winning Washington's and Moscow's support and security, or to retain its strategic arsenal and almost certainly lose Washington's and Moscow's support and security. U.S. and Russian security was certainly threatened for every additional minute Ukraine retained its arsenal. However, Ukraine's economic and diplomatic interests were increasingly threatened for every minute they held onto the arsenal. This condition overshadowed the advantages the weapons provided to Ukrainian military security - and these advantages were also deteriorating as the weapons aged. Ukraine decided that surrendering its nuclear weapons was the best option. Though Ukraine would be less militarily secure as a non-nuclear nation, Kiev hoped that surrendering the arsenal would make it more economically, diplomatically, and politically secure.

The second lesson the post-Soviet denuclearization case provides is that a potential nuclear state can be more easily persuaded to denuclearize when its nuclear weapon status is ambiguous or undeveloped. Though Ukraine, Belarus, and Kazakhstan were extreme case, because they woke up one morning in possession of nuclear arsenals, their cases are nonetheless instructive. None of the three republics had made a political or economical investment in developing nuclear weapons. Thus, they did not have established organizations invested in maintaining the arsenal or a reflexive aversion to eliminating the weapons.

The third lesson that the case of Ukraine provides is that it is important to be clear about what is and is not acceptable to a given state. The U.S. owes part of its success to the clarity of its commitment to remove nuclear weapons from Ukraine. Ukraine was never in any doubt that the U.S. would accept nothing less than complete removal of all nuclear weapons. This forced Ukraine to make an "all or nothing" decision about its strategic nuclear weapons.

The case of Ukraine also provides a fourth critical insight: the U.S.-Russia partnership for denuclearization succeeded where either state's unilateral effort would have failed. A successful deal required Moscow's openness in the warhead dismantlement phase and an acknowledgment of Ukraine's sovereignty—neither of which the U.S. could provide. The 
deal also required Washington's security guarantees, economic assistance, and third-party mediation efforts—-none of which Russia could provide. ${ }^{11}$

Another lesson that both the denuclearization of former Soviet republics and implementation of the Nunn-Lugar program in this region provide is that if the U.S. and Russia join forces as equal partners on an issue where their vital interests converge, then they can achieve results that may seem unattainable to others. Equality is as important for such breakthroughs as commonality of interests. The Nunn-Lugar program in Russia has showed the limits of cooperation when one partner in the project is a "recipient," the other is a "donor," and the former appears to be much more interested in the issue than the latter. Conservative elements of the Russian defense and security establishment have opposed expansion of the Nunn-Lugar program, arguing it is not in Russia's interest and is designed to let the U.S. officials spy on Russian nuclear secrets and incentivize the reduction of Russia's military nuclear potential. On the U.S. side, policymakers have complained that some of their Russian counterparts do not seem to be interested in sustaining security improvements funded under the program.

When the U.S. and Russia collaborated to denuclearize Ukraine, they did so as equal partners, even though their nuclear nonproliferation partnership was just beginning. That partnership has strengthened considerably since then, and Washington and Moscow now have the opportunity to lead the international community in reversing erosion of the international non-proliferation regime. The upcoming nuclear summit in Seoul gives the U.S. and Russia an excellent opportunity to display such leadership.

\footnotetext{
${ }^{11}$ Jim Walsh, "Russian and American Nonproliferation Policy: Success, Failure, and the Role of Cooperation," (Kennedy School of Government International Security Program, Discussion Paper, 2004).
} 


\section{NEXT STEP: GLOBAL ALLIANCE AGAINST NUCLEAR TERRORISM}

As the world's leading nuclear weapons states, the U.S. and Russia have a unique ability, and a unique responsibility, to lead in combatting the threat of nuclear proliferation and nuclear terrorism. The future of the global nuclear order will be determined to a large extent by whether Washington and Moscow agree on the diagnosis of the threat and jointly develop a strategy to combat it.

But the U.S. and Russia cannot undertake or sustain efforts to combat nuclear proliferation and nuclear terrorism bilaterally. Fortunately, they need not try. Today, all responsible nations share vital national interests in preventing nuclear proliferation and terrorism. Each has sufficient reason to fear nuclear weapons in the hands of terrorists, whether they are Al Qaeda, terrorist groups in Russia's North Caucasus, or doomsday cult members. Each nation's best hope to achieve conditions essential for its own security requires serious cooperation with the others. The great powers are therefore ripe for mobilization for a new global concert, indeed a grand Global Alliance Against Nuclear Terrorism.

Just as the U.S. government recognized the Soviet Union's dangerous legacy of tactical and strategic weapons and moved briskly to secure them, so all states with nuclear weapons should acknowledge this pressing threat to global security - a threat too large for one nation to tackle alone — and join this alliance.

The mission of the alliance should be to minimize the risk of nuclear terrorism by taking every action physically, technically, and diplomatically possible to keep nuclear weapons or materials locked away to a "gold standard" to prevent them from being acquired by terrorists. UN Security Council Resolutions 1373, 1540, and 1887 provide a UN framework for this alliance. They call for securing nuclear weapons, materials, and technologies by requiring all states to criminalize proliferation, enact strict export 
controls, and secure sensitive materials within their borders. While obliging sovereign states to adopt and enforce laws to close the loopholes exploited by black market WMD networks, these commitments currently lack necessary enforcement mechanisms. Such mechanisms should be created and codified as part of the global alliance. This alliance should incorporate lessons learned over the past twenty years through U.S.-Russian cooperation in agreeing on criteria for securing weapons and materials supported by Nunn-Lugar funds and the G-8 Global Partnership, and experience gained during implementation of earlier international projects, such as the Proliferation Security Initiative, that provide a framework for international cooperation among member states in fighting proliferation networks.

As nuclear superpowers who still control $95 \%$ of the weapons and materials, the U.S. and Russia would be the founding partners of the Global Alliance. They would invite other nuclear weapon states, and states with weapon-usable materials, to join. The central commitment of the Alliance would be to do everything technically feasible on the fastest possible timetable to prevent terrorists exploding a nuclear bomb. Operationally, this would require three clear commitments as the fixed entry price for membership at the high table of the Alliance:

- A gold standard for all nuclear weapons and materials on a country's soil, attaining the highest level of security to which other items of value can be protected. This "gold standard" would include:

- Steps to reduce the probability of theft to a level as low as reasonably achievable, as my Belfer Center colleague William Tobey has recommended. ${ }^{12}$

○ Protecting all HEU and plutonium against all insider and outsider threats that local intelligence services judge to be plausible.

\footnotetext{
${ }^{12}$ This and other recommendations below are in part based on William Tobey, "Planning for Success at the 2012 Seoul Nuclear Security Summit,” Policy Analysis Brief, Stanley Foundation, June 2011.
} 
- Transparency about having secured weapons and materials to this gold standard, sufficient for each of the leaders to assure citizens in his own country that if terrorists successfully explode a nuclear bomb, it will not have come from one of the other states who is a member of this Alliance, because they have not only pledged to secure their weapons to a gold standard, but also have actually done so. Compliance should be certified by independent international audits and tests of security. Such audits should become an integral part of the international process for operationalizing the "gold standard" in order to fill in the undefined "effective, appropriate" security required by UN Security Council Resolution 1540. There should be an ongoing process for holding states accountable beyond the end of the four-year effort agreed to in 2010.

- Cessation of all production of new HEU and plutonium that could be used in weapons.

The presidents of the U.S. and Russia could announce the Global Alliance at the Seoul summit and invite leaders of other nations to join them before the next nuclear security summit in 2014. The two presidents must use all their powers of persuasion and refuse to accept no for an answer.

As noted above, while the Washington summit took a giant step forward in addressing threats of nuclear terrorism, it failed to take other steps required for success. The participants were not able to agree on a shared assessment of the nuclear terrorism threat or establish an operational baseline and criteria for protection of weapons-usable material. The commitments listed in the communiqué were often vague or weakened by loopholes. Moreover, as observed by its organizers, the Washington summit picked most of the "low hanging fruit."

To accelerate progress in enhancing nuclear security, the U.S., Russia and other members of the proposed Global Alliance should commit themselves to taking the following actions between the 2012 and 2014 nuclear security summits: 
- Agreeing to declare all stockpiles of HEU and plutonium, limit further accumulation of such stockpiles, consolidate their storage facilities, and reduce these stockpiles as rapidly as practicable.

- Agreeing to end the civil use of HEU and to eliminate civil stocks of such material.

- Agreeing to eliminate particularly dangerous stocks of HEU or separated plutonium. For instance, the U.S. and Russia could expedite efforts to have research reactors modified to run on low-enriched uranium (LEU). Those reactors that cannot be converted to LEU must be closed.

- Agreeing that the nuclear-weapon-states that are signatories to NPT and any other states willing to join the new Global Alliance will formally commit to a fissile material production moratorium in a joint statement. This would be a political commitment and intended to add momentum to, not supplant, the Fissile Material Cut-off Treaty.

- Establishing national and regional fissile-material free zones. Ukraine, Belarus, and Kazakhstan could lead by example.

- Establishing joint capabilities to collect and analyze intelligence on nuclear terrorist threats.

- Agreeing that countries will provide on-site armed guards for all sites with HEU or separated plutonium, with numbers, training, and equipment sufficient to protect the sites against plausible threats until off-site forces arrive.

- Committing to carry out regular and realistic tests of nuclear security systems' abilities to counter attacks by adversaries in which insiders and outsiders collude.

- Committing to participate in exchanges of nuclear security best practices, to establish implementing programs for those practices at nuclear sites, and to participate in and support World Institute for Nuclear Security and IAEA security work. 
- Agreeing to implement the amended Convention on the Physical Protection of Nuclear Materials, even before its entry into force.

While leading efforts to enhance nuclear security worldwide though implementation of these measures under the auspices of the proposed Global Alliance, the U.S. and Russia should also bear in mind that there are still almost 20,000 nuclear warheads in their combined arsenals, far beyond what either requires for robust deterrence, including extended deterrence guarantees to allies. Therefore, Washington and Moscow should carry out a fresh round of deep bilateral nuclear arms reductions while also working to draw other nuclear powers into the disarmament process.

Some non-nuclear-weapons states are dragging their feet on more ambitious initiatives to prevent nuclear terrorism, on grounds of frustration, arguing that the nuclear-weaponsstates have not lived up to their commitments under the NPT to pursue disarmament in good faith. Sharply reducing Cold War arsenals and devaluing nuclear weapons in international relations would partially address these states' grievances. Complete nuclear disarmament, however, is a long-term goal. The urgent challenge for all nations is to staunch the current bleeding of the international non-proliferation regime, and to bring the risk of nuclear terrorism, which would change our world forever, to the lowest level possible. 


\section{APPENDIX: GRAHAM ALLISON'S MEMO TO COLIN \\ POWELL}




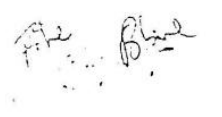

HARVARD UNIVERSITY

JOHN F. KENNEDY SCHOOL OF GOVERNMENT

GrahaM ALLISON

Dougias Dillon Professot of Government सitis
79 JOHN E. KENNEDY STREET CAMBridez, MassactivestTs 0213 (617) $495-1399$ FAX $(6: 7) 495-5303$

$9 / 6 / 91$

Private

To:

General Colin Powell

From:

Graham Allison

Re:

Sounding an Alarm: Soviet Disunion and Threats to American National Security

Date: Sept. 6, 1991

I am just returning from my second quick trip to Moscow in as many weeks. In between, I have been on the phone with folks daily. This has mainly involved support for Soviet friends who stood down the coup and are now trying to stand up under the weight of responsibility for the collapsing economy and polity. My colleague Yavlinsky finds himself as a member of the four-man committee charged with "managing" the government in the transition. Specifically, he is preparing a framework and program for radical economic reform. But I am also talking regularly to a couple of dozen other associates there including people in Yeltsin's first circle, Gorbachev's first circle, key instituniks, and a long term friend whom I believe to be the best informed civilian about Soviet military forces and defense enterprises.

Trying to distill several thoughts on the plane returning from Moscow to New York, I must say that my single largest worry-- accented by this most recent visit--is that rapid Soviet disunion will mean rapid disintegration of Soviet military forces including the nuclear arsenal. This worry is deeply felt by knowledgeable individuals in Yeltsin's first circle, as well as some around Gorbachev. It approaches a state of alarm for the individual whom I have found the most reliable Soviet on these matters over the years.

As of yesterday, basically all the republics had declared independence. The Ukraine has asserted control over all military facilities on its territory. Others are discussing equivalent assertions. Operationally, the meaning of such assertions is ambiguous, but sliding in unpleasant directions. The distinction between the real and the surreal has been difficult at all recent times in the Soviet Union and becomes ever more so. Events move like quicksilver. Pregnant pauses are followed by rapid bursts of movement in directions difficult to predict. But if one looks carefully at the tilt of the surface on which the quicksilver is resting, one can assess the probabilities.

What Happened to the Soviet Superpower's Nuclear Arsenal?

Clues for the Nuclear Security Summit 
Disintegration of a unified Soviet nuclear arsenal poses two distinct problems: one more deadly, the other more likely. Division of strategic nuclear forces located in the Ukraine, Kazakhstan, Byelorussia, and Russia itself (where various autonomous regions from Tartars to Kossacks are stirring with national aspirations) is worrisome enough. But if one recalls our real concern about an Iraqi nuclear weapon, the non-strategic nuclear weapons depots in assorted other republics require immediate attention.

1) The Problem: Soviet disunion could create additional nuclear states, provoke struggles for control of Soviet nuclear weapons, and lead to a loss of control of strategic or nonstrategic nuclear weapons. As of yesterday:

* Ukraine: Deadly serious about independence without understanding what that will inevitably mean for confrontation with the Soviet Union over the Crimea (which Khrushchev transferred from Russia to the Ukraine in the 1950s) as well as likely intra-Ukrainian separatists (between Western Ukrainians and Russians in the Eastern Ukraine); last week's asserted full independence including control over all military facilities in the Ukraine; an emerging but serious discussion of an independent Ukrainian armed force of 500,000 men (that is larger than the Bundeswehr); having inherited a position that calls for the Ukraine to be a nuclear free zone (in order to rid themselves of Russian nuclear weapons) which was reiterated last week including a statement that it was prepared to have nuclear weapons transferred from the Ukraine to Russian territory; a first circle around Kravchuk (President of the Ukraine) that is just beginning to think of the relevance of nuclear weapons, especially if conflict with Russia is likely. One of the most telling indicators of things to come was the republic's statements by Shcherbak, the Ukraine's leading Democrat. As he stated in Moscow, when he first became a member of the Union Supreme Soviet, all his friends and associates were Russian Democrats. But last week he discovered that whether Democrat or Communist--all Russians are alike and are a powerful threat to the Ukraine. He is interested in defending the Ukraine by all possible means.

* Kazakhstan: Nazarbayev is more complicated. (Yavlinsky has been his chief economic advisor). He is tough, an advocate of the market, but more admiring of Li Quan Yu than more sympathetic Western democratic figures. He now thinks of Kazakhstan as a nuclear state--but I suspect that he doesn't know what part of that thought is real and what fanciful. When Russia stated last week that it would assert territorial claims against any republic that left the Union, Nazarbayev stated quite deliberately: any assertion of territorial claims against Kazakhstan could lead to war. He has closed down the nuclear testing facility in Kazakhstan because of long standing local environmental opposition. But he is acutely conscious that Western Kazakhstan, which contains the SS-18 fields, is mainly populated by Russians and is certain to be the subject of intense dispute between an independent Russia and an independent Kazakhstan.

What Happened to the Soviet Superpower's Nuclear Arsenal?

Clues for the Nuclear Security Summit 
* Byelorussia: Long the most conservative of the European republics, Byelorussia declared independence last week. The Communist leadership there, particularly since it had been sympathetic to the coup, is seeking to align itself with more popular nationalism and to hold onto the property of the Communist party that would otherwise have been seized by the Union under Gorbachev's declaration. There are reports, the validity of which I cannot vouch for, that local military commanders, some who were favorable to the coup, fear the consequences of returning to Russia and thus have stakes in independent armed forces in Byelorussia.

In addition, there are the republics with storage depots of non-strategic nuclear weapons and potential claimants of independence among autonomous regions within Russia.

2) Short-Term Prospects: Natural forces will lead to a growth, not diminution, of nuclear appetites.

Given the pace of events, especially in the context of August vacations, the temptation to "wait for events to clarify" is tempting. It is also deeply mistaken. As Churchill explained best: acting before events clarify risks choosing counterproductive initiatives. As he observed, if France or Britain had resisted Hitler in 1936 when Germany remilitarized the Rhineland, or even in 1938 during Germany's confrontation with Czechoslovakia, the German generals would almost certainly have tumed Hitler out of office. WWII, as we knew it, would have been avoided. Waiting for events to clarify forfeits the opportunity to exercise leverage in shaping outcomes.

No one can say what will happen in the Soviet Union. What we can do is identify alternative futures that mav happen, analyze forces that will nudge developments in one direction or another, be clear about our interests, and exercise whatever leverage we have to seek to minimize the likelihood of outcomes totally unacceptable to us.

That is one description of the nuclear deterrence problem we have been working for more than four decades--with considerable success. I believe that we can draw useful lessons from that experience in trying to cope with the current ongoing revolution. Specifically, even very low probabilities of outcomes that have infinite disutility for us must concern us greatly. Actions likely to lower the probability of low probability events are frequently prudent. Thinking about all conceivable ways a nuclear weapon could be used against us or our vital allies, and seeking to reduce the risks of such use to the lowest possible level requires eternal vigilance. What requires new thinking in the current situation are unfamiliar scenarios and unusual instruments for influence.

The good news today is that Chernobyl and the nuclear testing program in Kazakhstan produced a nuclear allergy and generated vocal public pressure for becoming nuclear free zones. The bad news is that by next week or next month this allergy may be overridden by the logic of geopolitics.

What Happened to the Soviet Superpower's Nuclear Arsenal?

Clues for the Nuclear Security Summit 
In the accelerating Soviet disunion, there is an emerging discussion of division of assets and liabilities: external debt, gold reserves, military capabilities, defense enterprises, etc. As new leaders feel the weight of responsibility of a rapidly declining economy, and discover that they are being held accountable by their local constituents, their demand for more of all assets will certainly grow. The concept of being truly independent is still so new to most of them that they are just coming to learn one of the first lessons of geopolitics. Any independent small power adjacent to a large power with which it has substantial territorial and ethnic disputes has a security problem. No geopolitician would voluntarily choose to be a non-nuclear state facing a major power that was a nuclear state. Nor would any strategist advise them to. Nor, I suspect, would any commanders of forces whose military district, or wings, or divisions have had nuclear weapons.

Thus, as quickly as they recognize their real interest, they will be really interested in maintaining whatever nuclear arsenals they can.

3) What Is To Be Done Now?

I think the main message is to hear the alarm and to organize appropriate task forces to start working the problem: tracking developments, identifying threats, identifying points of leverage, etc. What follows is just a sketch of the kinds of actions that I believe that I would take (were it my responsibility) listed under three categories: immediate, medium term, and longer term.

* Immediate (this week)

$>$ In the current process of recognizing and establishing normal diplomatic relationships with the Baltics, now--today--insist that the U.S. will establish diplomatic relations with new republics only on the basis of their affirmation of their willingness to comply with international treaty commitments taken by the Soviet Union: specifically, the Non-Proliferation treaty (which committed one Soviet Union not to transfer nuclear weapons to third parties or to assist third parties in acquiring nuclear weapons and which new states must now join as nonnuclear weapons states); START, CFE (and the reductions of forces in prescribed areas to fixed levels which, for example, the Ukrainian forces now being discussed would violate), CSCE (and the guarantees for individual human rights affirmed there), and perhaps others.

It is essential that this be the benchmark for the U.S. and our Western allies in recognizing and establishing diplomatic relations with the Baltics right now so that this precedent is clearly set as part of our attempting to shape expectations in other republics.

Explore cooperative measures with the Soviet and Russian government to return all nuclear warheads to Russian territory immediately. After no more than three

What Happened to the Soviet Superpower's Nuclear Arsenal?

Clues for the Nuclear Security Summit 
days' thought about various initiatives, an emissary should go to Moscow to pursue this issue quietly at the highest level. I have good reason to believe that it will be well received in both the Russian and Soviet governments. We should be prepared to take whatever actions on our side would motivate, assist, or facilitate the completion of this task in the next several weeks. This may not require any parallel action on our part. But obviously, they are concerned about taking unilateral actions that imply a willingness to accept full independence of the Ukraine, Kazakhstan or Byelorussia. Our challenge is to make this as natural as possible. I have not worked the numbers, but can imagine parallel announcements by the Soviet and American governments that each is moving immediately to reduce nuclear danger by taking the first step in implementing the unratified START treaty by deactivating (denuclearizing) a number of nuclear weapons launchers (which happens to include all land based strategic nuclear missiles outside Russia). Similar parallel unilateral announcements could be made that all land-based non-strategic nuclear weapons would be withdrawn from the forces and retumed to a single central reserve (as we are in fact already doing). An analogous initiative could be taken for the sea-based non-strategic nuclear weapons. I haven't been able to think of an air-born non-strategic nuclear weapons equivalent that wouldn't pose large difficulties for us, but perhaps someone else can, etc.

* $\quad$ Medium-Term (during the month of September)

$>$ Organize a strategy for military-to-military cooperation on controlling nuclear risks, limiting the spread of nuclear weapons, increasing the security of command and control, etc. If we have a strong mutual interest with the Russian military in maintaining unified command and control of all nuclear weapons, they should feel that we are working with them to a common end. This is not easy, particularly since we also work actively to be able to threaten their strategic nuclear forces.

But a continuation of conversations like those between you and Moiseyev or Butler (and his counterpart) that demonstrated a willingness to address their sensitivities about Westem forces, communicated a willingness to cooperate and work with them, would, I think, pay high dividends.

$>$ Establish a govemment-wide strategy of creating, building, and reinforcing the expectation that normal nations are non-nuclear, non-chemical, non-biological, and non-missile bearing. So, as per above, for recognition, establishment of normal diplomatic relations, and any assistance. As folks are tempted to do otherwise, we have to be prepared to make them understand that they will become pariahs. Since those who are creating new states that have domestic constituents here in the U.S., we have got to get this line drawn first, fast, and upfront.

What Happened to the Soviet Superpower's Nuclear Arsenal?

Clues for the Nuclear Security Summit 
$>$ Establish a joint U.S.-Soviet-Republics Defense Enterprise Conversion Fund that targets production facilities that would be most threatening to us if a republic were independent or if it were to produce or export. I have a more elaborate proposal for this. I think that we have to be working actively with them to assure that enterprises now producing nuclear weapons, missiles, and other especially threatening weaponry not continue such production for an independent republic or for export. My proposed U.S.-Soviet Defense Enterprise Conversion Fund would operate government-sponsored insurance through a special facility in OPIC. It would sell government guarantees against sovereign risks for approved U.S. private investments in converting Soviet defense enterprises. These could be investments in non-military production in existing enterprises. But what will be most likely are investments in new enterprises spun out of existing defense enterprises. We would then encourage specific American defense enterprises to take a great interest in particular Soviet enterprises.

$>$ Explore a U.S.-COCOM-Soviet (and perhaps even Eastern Europe) consortium to limit the sale of especially dangerous weaponry and technologies to third parties in the same way that Czech President Havel has discovered that 8000 jobs in a tank factory count for all his worthy pledges about stopping Czech arms exports. In newly independent republics with enterprises producing SS-18s or $24 \mathrm{~s}$ in the Ukraine, for example, or nuclear materials, will choose work rather than unemployment. With a limited amount of government support and encouragement and support, American enterprises can carry a good part of this load. But this requires action soon.

$>$ Limiting U.S. military and diplomatic actions that will appear threatening to the Soviet Union in ways that could provoke opposition to the weapon withdrawals receipt. So, e.g., U.S. naval and air operations near the Soviet Union, NATO exercises, etc.

* $\quad$ Longer-Term (next three months)

$>$ Develop and implement a strategy for increasing our leverage in these developments. My preferred strategy is, as you know, a grand bargain: a U.S.led G-7 (or G-24) program of substantial and sustained assistance to the Soviet Union and its republics if and when--but only if and when--they meet the essential conditions for that assistance to be used effectively. These conditions include not only that they adopt and begin implementing a coherent economic reform program. Those eligible for such assistance must also be respecting human rights in their territory, not proliferating, and working cooperatively in a coherent economic and political community.

The saddest feature of the "debate" that has taken place on this issue is that the United States and its allies are spending the money but forfeiting the leverage.

What Happened to the Soviet Superpower's Nuclear Arsenal?

Clues for the Nuclear Security Summit 
While insisting that we cannot mount a coherent program, the U.S. has nonetheless committed $\$ 2.5$ billion for credits for food in 1991. The U.S. share of the largest financial package that I have seen calculated for any "grand bargain" would be $\$ 3$ billion of a $\$ 30$ billion a year package. The point is not money but a strategy for leverage on behalf of our interests.

I have got some more ideas, but that is enough to get started. I will call your office early next week to see if I can be of any assistance in moving this issue forward.

Thanks for hearing me out.

P.S. One initiative that might seem to, but in fact would not advance our interests here is further reductions in U.S. defense spending. Blackwill and I thought hard before including in our Foreign Affairs piece the judgment that: "no event in the post-war period would pose such a high and uncontrollable risks of nuclear war as the violent disintegration of the Soviet Union into chaos and civil wars." Churchill's dictum deserves repeating: the resolution of the grievances of the vanquished must precede the disarmament of the victors.

What Happened to the Soviet Superpower's Nuclear Arsenal?

Clues for the Nuclear Security Summit 


\section{Belfer Center for Science and International Affairs}

John F. Kennedy School of Government

Harvard University

\section{JFK Street}

Cambridge, MA 02138

Fax: (617) 495-8963

Email: bcsia_ksg@harvard.edu

Website: http://belfercenter.org

Copyright 2012 President and Fellows of Harvard College

What Happened to the Soviet Superpower's Nuclear Arsenal? Clues for the Nuclear Security Summit 